\title{
Exchange of Astronomy Teaching Experiences
}

\author{
Rosa. M. Ros
}

Department of Applied Mathematics IV, Technological University of Catalonia, Jordi Girona 1-3, Modul C3, 08034 Barcelona, Spain. e-mail: ros@mat.upc.es

\begin{abstract}
The Working Group of the European Association for Astronomy Education responsible for Teacher Training organises an annual Summer School for teachers under expert guidance. For a week the teachers participating can exchange experiences, increase their knowledge and discuss different ideas and perspectives.

In general, the instructors are professional astronomers, professors and teachers from different countries. The papers presented offer very practical activities, paying special attention to didactic aspects, and take the form of general lectures to all 40 participants and workshops to reduced groups of 20 participants. There are also day and night observations, without expensive equipment or complicated procedures, that are easy to set up and based on topics that it is possible to use in the classroom.
\end{abstract}

'The Summer Schools promote a scientific astronomical education at all levels of astronomy teaching, reinforce the link between professional astronomers and teachers with experience of teaching astronomy, allow debates among the participants on their pedagogical activities already carried out in their own classroom and help them to organise activities outside it.

Astronomy teachers need special training, access to specific research, to new educational materials and methods and the opportunity to exchange experiences. All these things are provided by the Summer School.

\section{Presentation of EAA}

The European Association for Astronomy Education (EAAE) is an association which brings together European teachers and lecturers interested in astronomy. The EAAE was born under the auspices of ESO in 1994 in Garching, but EAAE started its work during the Founding General Assembly in Athens (November 1995). The Web page of EAAE is:

http://www.algonet.se/ sirius/eaae/workgrps.htm.

The aims of the EAAE are to improve and promote scientific astronomical education in Europe in schools of all levels and other institutions involved in 
teaching Astronomy, to reinforce the link between professional astronomers and school teachers with experience of teaching astronomy at various levels, to allow debates between participants on the pedagogical activities already carried out in their own classroom, and to organise activities outside it.

The EAAE has a set of working groups in various fields (Table 1) and has 20 member countries (Table 2).

Table 1. The Working Groups of the EAAE
- No. 1. Astronomical Concepts
Chairperson: Rainer Gaitzsch
e-mail: gaitzsch@ikra.med.uni-muenchen.de
- No. 2. Didactic Materials
Chairperson: Lidia Nuvoli
e-mail: palici@aerre.it
- No. 3. Training Teachers
Chairperson: Rosa M. Ros
e-mail: ros@mat.upc.es
- No. 4. European Student Projects
Chairperson: Mogens Winther
e-mail: mw@posthu.amtsgym-sdbg.dk
- No. 5. Public Education
Chairperson: Thomas W. Kraupe
e-mail: TWK@artofsky.com
- No. 6. Projects for EAAE
Chairperson: Bernard Pellequer
e-mail: bernard.pellequer@cnusc.fr

Teachers need to receive in-service education in order to teach astronomy effectively. They need special training, access to specific research, to new educational materials and methods and the opportunity to exchange experiences. This happens during the summer schools which the EAAE organises.

This is the real spirit of the EAAE-WG3 working group for teacher training. The principal objective of this group of professors and teachers, established in Athens in November 1995, is the organisation of the EAAE International Summer Schools. Good teacher education leads to better student education.

\section{Past European Summer Schools}

The working group for teachers' training (EAAE-WG3), organises a summer school each year for primary-schol and secondary school teachers under the guidance of experts. For a week the teachers participating can exchange experiences, increase their knowledge and discuss different ideas and aspects in a friendly atmosphere. A general view of this training and a variety of pedagogical activities can be seen in the poster entitled "Summer Schools for European teachers to 
Table 2. The National Representatives of the EAAE

- Austria: G. Rath

e-mail: rath@borg-6.borg-graz.ac.at

- Belgium: E. Perotte

e-mail: eddy.pirrotte@skynet.be

- Denmark: Bent Klarmark e-mail: klamark@post4.tele.dk

- Estonia: L. Leedjrv

e-mail: leed@aai.ee

- Finland: M. Sarimaa

e-mail: markku.sarimaa@ursa.fi

- France: B. Pellequer

e-mail: bernard.pellequer@cnusc.fr

- Georgia (Republic of): T. Borchkadze

e-mail: tenat@dtapha.kheta.ge

- Germany: Roland Szotak

fax: +49-(0)251-833669

- Greece: M. Metaxa

e-mail: mmetaxa@compulink.gr

- Italy: Cristina Palici di Suni e-mail: palici@aerre.it
- Latvia: Ilgonis Vilks

e-mail; vilks@latnet.lv

- Luxembourg: F. Wagner

e-mail:

fernand.wagner@ci.educ.lu

- The Netherlands:

Gert Schooten

e-mail: Gert.Schooten@quant.nl

- Norway: F. Pettersen

e-mail:

franck.pettersen@unikom.uit.no

- Portugal: M.F.S. Martins

e-mail: felisbela.martins@ip.pt

- Russia: Michael G. Gavrilov

e-mail: gavrilov@issp.ac.ru

- Spain: E. Zabala

e-mail: ezabala@sinix.net

- Sweden: B. Lingons

e-mail: bjlin@avc.edu.stockholm.se

- Switzerland: M. Reichen

e-mail:

michael.reichen@obs.unige.ch

- U.K. M. Cohen

e-mail: amc@rmplc.co.uk

increase the quality and presence of Astronomy in European Curricula" (see p. 166).

The first Summer School was organised in La Seu d'Urgell (Spain, 1997), a small town in the Pyrenees, near the border with France, in a good observational zone. The second EAAE International Summer School was held in Fregene (Italy, 1998). This town, in the Mediterranean area, is near Rome and this location was used to offer the participants an interesting walking tour of Rome from an astronomical perspective. The third Summer School took place in Briey (France, 1999), a small village in the central area of the solar eclipse of August 11th. The participants were able to observe the eclipse and take part in different activities related to it. The fourth Summer School (Portugal, 2000) took place in Tavira, a small village in the Algarve on the Atlantic coast, near Sagres, birthplace of Portuguese maritime exploration. The theme was "Astronomy and Navigation", and the participants had the chance to practice using some old astronomical tools, on a boat trip. In all cases, there was a group of around 50 participants from several European countries which appear in Table 3.

In general, the participants were European teachers from secondary schools and to a lesser extent, there were some teachers from primary schools and planetarium employees. The instructors were professional astronomers, professors and teachers from different countries. The papers that were presented covered very practical activities, paying special attention to didactic aspects, and took the 
Table 3. Countries at the EAAE Summer Schools

\begin{tabular}{lrrrr}
\hline Country & $\begin{array}{r}\text { First } \\
\text { School }\end{array}$ & $\begin{array}{r}\text { Second } \\
\text { School }\end{array}$ & $\begin{array}{r}\text { Third } \\
\text { School }\end{array}$ & $\begin{array}{r}\text { Fourth } \\
\text { School }\end{array}$ \\
\hline Austria & 0 & 1 & 1 & 1 \\
Belgium & 1 & 1 & 2 & 2 \\
Denmark & 0 & 0 & 1 & 0 \\
Finland & 2 & 3 & 2 & 4 \\
France & 14 & 11 & 13 & 3 \\
Georgia & 0 & 2 & 0 & 1 \\
Germany & 3 & 1 & 2 & 3 \\
Greece & 0 & 1 & 0 & 1 \\
Italy & 5 & 15 & 5 & 3 \\
Latvia & 1 & 0 & 1 & 3 \\
Luxembourg & 0 & 0 & 1 & 0 \\
Netherlands & 0 & 0 & 3 & 1 \\
Portugal & 1 & 2 & 4 & 13 \\
Russia & 0 & 0 & 0 & 1 \\
Spain & 20 & 10 & 14 & 9 \\
Sweden & 0 & 0 & 2 & 0 \\
Brazil & 0 & 0 & 0 & 1 \\
Chile & 0 & 0 & 1 & 0 \\
& & & & \\
Total & 47 & 47 & 52 & 46 \\
\hline
\end{tabular}

form of general lectures to all participants and working groups, and workshops to reduced groups of 15-20 participants. There were day and night observations based on topics possible to introduce in the classroom.

At the end of the Summer School a questionnaire is answered by the participants to evaluate the activities carried out. The results are used for planning subsequent Summer Schools. This kind of work leads to the Summer School being modified in some aspects every year, in order to adapt its contents to the general interest of the teachers who attended the conference.

At the first Summer School the activities were of a more theoretical nature than at the last one, which included as many workshops as possible about practical subjects and models for building. The time for encouraging general discussion was also increased. Our participants greatly enjoy explaining the situation in their countries and comparing it with others. Despite the initial opinions of those attending, the differences between the European countries are minimal and the general situation is common. In the majority of European countries, astronomy appears as topics included in different subjects. The largest number of topics can be found in physics, but some of them appear in geography, mathematics, geology and other scientific subjects. This interdisciplinary aspect of astronomy currently causes its dispersion among many subjects with the consequent problems. However, this situation can be used to introduce astronomy from all the teaching fields if the teachers are adequately trained. This is our objective in 

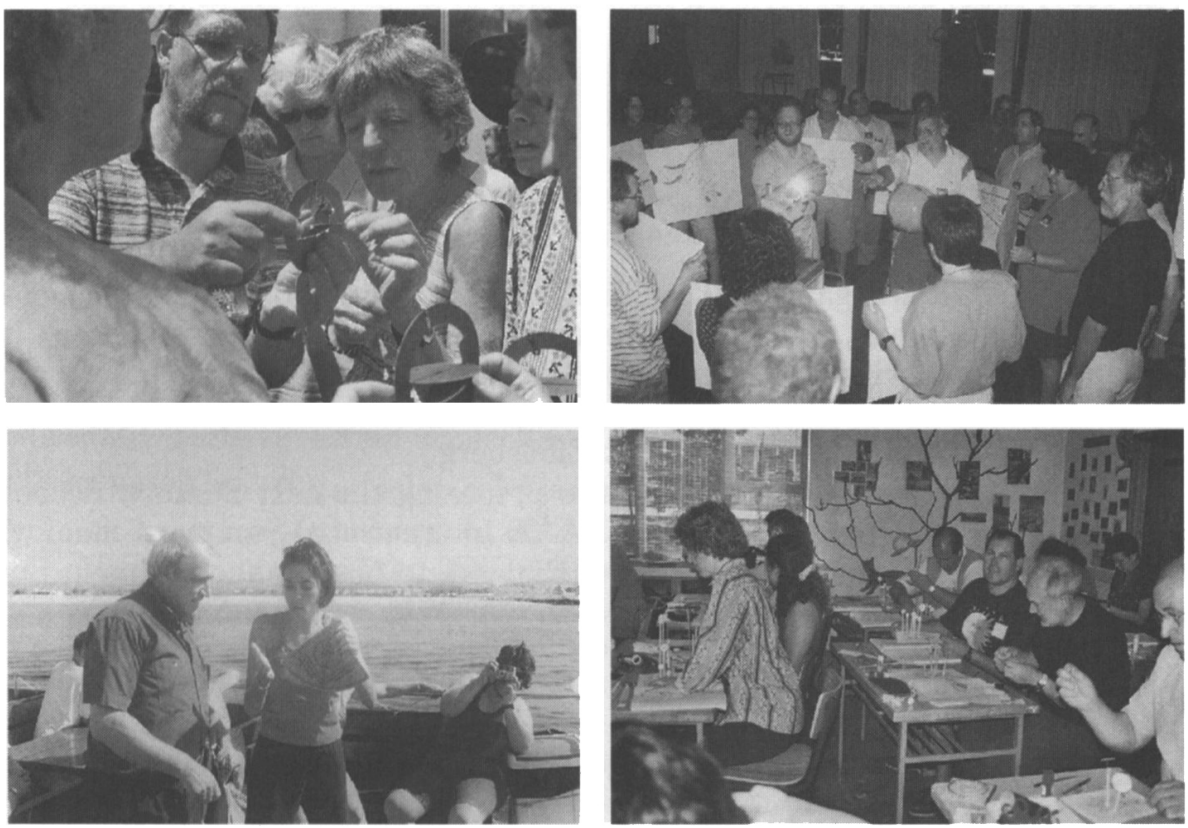

Figure 1. Teachers engaged in various Summer-School activities

the Summer School: to give teachers a lot of ideas, resources and facilities in order to explain more and more astronomy from all the different fields.

The importance of the poster session has gradually increased at every Summer School. This session offers participants the opportunity to present their works in the classroom environment with their students. On the first or the second day of the conference, each participant who wants can present his poster to the rest of the members of the Summer School. Throughout the week, the poster can be visited by the rest of the participants. This promotes the exchange of information between all the teachers, lecturers, and astronomers who attend the Summer School.

At the last event organised, a new point of interest was introduced: the Bazaar. This is a marketplace area which can be visited during the Summer School where the participants place astronomical materials to exchange, sell and buy (booklets, photocopied material, dossiers, models, tools, instruments, computer programs, CD-ROMs). The main aim of the organisers at all times is to facilitate contacts between all the participants. A very friendly general atmosphere promotes this situation, and is maintained despite the intensities of a week living together.

The topics presented at the summer schools appear in the poster mentioned previously.

The Summer School has three different languages to facilitate teachers' participation. The languages are the language of the host country, as well as 
English, and one other, which can be used by the majority of participants. Although the lingua franca of the Summer School is English, a printed document (Ros 1997, 1998, 1999, 2000) with the contents of all the papers in two languages (English and one of the other official languages) is given to participants and instructors so that they can follow the meeting more easily. This document promotes understanding between all the participants.

\section{Future Summer Schools}

The EAAE-WG3 is organising the 5th EAAE International Summer School in Bad Honnef (Germany, 2001). The Summer School will be held from 2nd to 7th July and the topic will be Astronomy at the Dawn of the Third Millenium. The place selected, Bad Honnef, is a small village near Bonn. The participants will be able to visit the Radio-Telescope at Effelsberg.

The WG3 on teacher training is also preparing the next Summer Schools. We are able to announce that the 6th EAAE International Summer School will be held in Pallas, in the Lapland area of Finland, to observe the Midnight Sun, during the second week of July 2002.

\section{References}

Ros, R.M. (ed.) 1997, Proceedings of 1st EAAE International Summer School Institut de Cincies de l'Educaci. Universitat Politcnica de Catalunya. Barcelona, 1997. ISBN: 84-89190-21-6.

Ros, R.M. (ed.) 1998, Proceedings of 2nd EAAE International Summer School Institut de Cincies de l'Educaci. Universitat Politcnica de Catalunya. Barcelona, 1998. ISBN: 84-89190-24-0.

Ros, R.M. (ed.) 1999, Proceedings of 3rd EAAE International Summer School Unitat de Formaci de Formadors. Universitat Politcnica de Catalunya. Barcelona, 1999. ISBN: 84-89190-25-9.

Ros, R.M. (ed.) 2000, Proceedings of 4th EAAE International Summer School Unitat de Formaci de Formadors. Universitat Politcnica de Catalunya. Barcelona, 2000. ISBN: 84-89190-26-7.

\section{Discussion}

Hingley suggested that one problem of astronomy texts is variable and erratic selection of topics. Could the EAAE compile lists of topics at various levels which would constitute a "core curriculum"? Ros replied that this was indeed a topic of interest for the EAAE and it would be discussed at the fifth school. (Editor's note: see also the abstract of Ros's poster on p. 166.) 